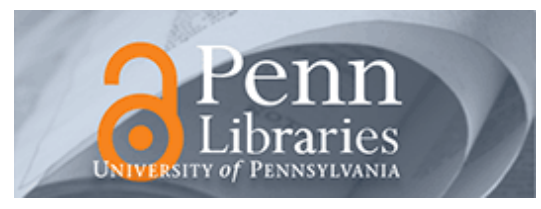

University of Pennsylvania

ScholarlyCommons

Management Papers

Wharton Faculty Research

$9-2011$

\title{
Learning From Developing Country Experience: Growth and Economic Thought Before and After the 2008-2009 Crisis
}

Ann E. Harrison

University of Pennsylvania

Follow this and additional works at: https://repository.upenn.edu/mgmt_papers

Part of the Business Administration, Management, and Operations Commons, and the International Business Commons

\section{Recommended Citation}

Harrison, A. E. (2011). Learning From Developing Country Experience: Growth and Economic Thought Before and After the 2008-2009 Crisis. Comparative Economic Studies, 53 (3), 431-453. http://dx.doi.org/ $10.1057 /$ ces. 2011.6

This paper is posted at ScholarlyCommons. https://repository.upenn.edu/mgmt_papers/85

For more information, please contact repository@pobox.upenn.edu. 


\title{
Learning From Developing Country Experience: Growth and Economic Thought Before and After the 2008-2009 Crisis
}

\author{
Abstract \\ The aim of this paper is twofold. First, we document the changing global landscape before and after the \\ crisis, emphasizing the shift toward multipolarity. In particular, we emphasize the ascent of developing \\ countries in the global economy before, during, and after the crisis. Second, we explore what these global \\ economic changes and the recent crisis imply for shifts in the direction of research in development \\ economics. We place a particular emphasis on the lessons that developed countries can learn from the \\ developing world.

\section{Keywords} \\ growth, economic development, international economic order, trade, welfare programs, income \\ distribution, economic development, technological change and growth

\section{Disciplines} \\ Business Administration, Management, and Operations | International Business
}




\title{
Policy Research Working Paper 5752
}

\section{Learning from Developing Country Experience}

\author{
Growth and Economic Thought Before and After \\ the 2008-09 Crisis
}

\author{
Ann Harrison \\ Claudia Sepúlveda
}

The World Bank

Development Economics Vice Presidency

August 2011 
Policy Research Working Paper 5752

\begin{abstract}
The aim of this paper is twofold. First, it documents the changing global landscape before and after the crisis, emphasizing the shift towards multipolarity. In particular, it emphasizes the ascent of developing countries in the global economy before, during, and after the crisis.
\end{abstract}

Second, it explores what these global economic changes and the recent crisis imply for shifts in the direction of research in development economics. The paper places a particular emphasis on the lessons that developed countries can learn from the developing world.

This paper is a product of the Development Economics Vice Presidency. It is part of a larger effort by the World Bank to provide open access to its research and make a contribution to development policy discussions around the world. Policy Research Working Papers are also posted on the Web at http://econ.worldbank.org. The author may be contacted may be contacted at ann.harrison@berkeley.edu and Csepulveda@worldbank.org.

The Policy Research Working Paper Series disseminates the findings of work in progress to encourage the exchange of ideas about development issues. An objective of the series is to get the findings out quickly, even if the presentations are less than fully polished. The papers carry the names of the authors and should be cited accordingly. The findings, interpretations, and conclusions expressed in this paper are entirely those of the authors. They do not necessarily represent the views of the International Bank for Reconstruction and Development/World Bank and its affliated organizations, or those of the Executive Directors of the World Bank or the governments they represent. 


\title{
Learning from Developing Country Experience: Growth and Economic Thought Before and After the 2008-09 Crisis ${ }^{1}$
}

\author{
Ann Harrison and Claudia Sepúlveda \\ The World Bank
}

\footnotetext{
${ }^{1}$ We thank Indira Rajaram and Arvind Subramanian for their helpful comments, as well as other participants at the "Restoring Inclusive Growth in Advanced Economies: A Conversation with Economists and Policy Makers from G-20 Countries," conference held at New York University on October 7, 2010. Cristina Constantinescu and Jing Cai provided excellent assistance. 


\section{Introduction}

The 2008-9 financial and economic crisis has shown that the world economy and its recovery are much more fragile and interdependent than previously thought. The crisis has also revealed that we are in a new world, with multiple sources of growth and new powerful links between developing and developed countries and among developing countries. The crisis accelerated the change in the global economic landscape, one in which developing countries have acquired increasing importance in global economic growth and share of global GDP. Nearly half of global growth today comes from developing countries.

The crisis and the new global economic landscape that has emerged with developing countries taking center stage has not only given rise to the Group of 20 (G-20) as the relevant forum for global economic cooperation, but it has also compelled policymakers and researchers to question whether development economics in its present form is well positioned to tackle the most urgent issues of the day. What can developed countries learn from the rise of the emerging economies? These two landmark developments, the severe 2008-2009 crisis and the changing global landscape, have led to a serious questioning of the old orthodoxy.

The aim of this paper is twofold. First, we document the changing global landscape before and after the crisis, emphasizing this shift towards multipolarity. In particular, we emphasize the ascent of developing countries in the global economy before, during, and after the crisis. Second, we explore what these global economic changes and the recent crisis imply for shifts in the direction of research in development economics. We place a particular emphasis on the lessons that developed countries can learn from the developing world.

We emphasize four sets of issues that deserve attention moving forward. First, we emphasize the importance of structural transformation in the process of economic development, and the role that the government can play in accelerating or retarding that process. Second, we discuss the importance of promoting inclusive growth, which we refer to as broadening opportunities. Third, we highlight the increasingly risky global environment, with fluctuations in weather, capital flows, and trade highlighted in particular. Finally, we underline the importance of aid effectiveness, and seek to understand how we can better learn from results. These four areas we 
refer to as the "TORR" framework, which is shorthand for a focus on transformation, opportunities, risks and results.

The paper is organized as follows. Section 1 presents stylized facts of the global economic landscape since the early 1980s and projections into 2030. Section 2 discusses the researchable questions and lessons that have emerged post-crisis, grouped into four set of issues: Transformation, Opportunities, Risk, and Results (TORR). The last section concludes.

\section{A New Global Economic Landscape}

The increasing importance of developing countries in the new global economy and in the global political arena was evident long before the 2008-09 crisis. The crisis-which originated in the developed countries and affected them more severely--only served to reinforce the recognition of decade-long shifts in the global economy. This new global economic landscapein which developing countries are playing a central, if not lead, role-was acknowledged in November 2008 when for the first time the Group of 20 (G-20) leaders convened in Washington, D.C., to consider cooperative efforts to cope with the financial crisis and to lay the foundations for restoring sustainable and balanced growth. ${ }^{2}$

\section{Before the Crisis: Stylized Facts}

The increasing globalization that the world has experienced in recent decades - supported by multilateral trade policy reforms, broad liberalization in domestic trade and investment environments, and technological advances-has facilitated the acceleration of growth in developing countries and, by extension, the importance of these countries in the global economy. These changes in the global economic landscape are not the outcome of the crisis, but rather the result of decade-long shifts, as discussed below.

If we use a conventional measure of trade volumes, such as export shares in GDP, developing countries are now more integrated into the world economy than developed countries. Figure 1 shows that developing country exports surpassed developed country exports as a share of GDP in the early 1990s. By the mid-2000s, developing country shares of exports in GDP exceeded developed countries by at least 5 percentage points of GDP. Figure 1 also documents

\footnotetext{
${ }^{2}$ See Fardoust, Kim, and Sepulveda (2011).
} 
China's incredible export surge in the last 30 years. China overtook the developed country average in the mid-1990s, and surpassed the developing country average around the same time that it entered the WTO, at the end of 2001.

Figure 1 Export Shares in Developing and High-Income Countries

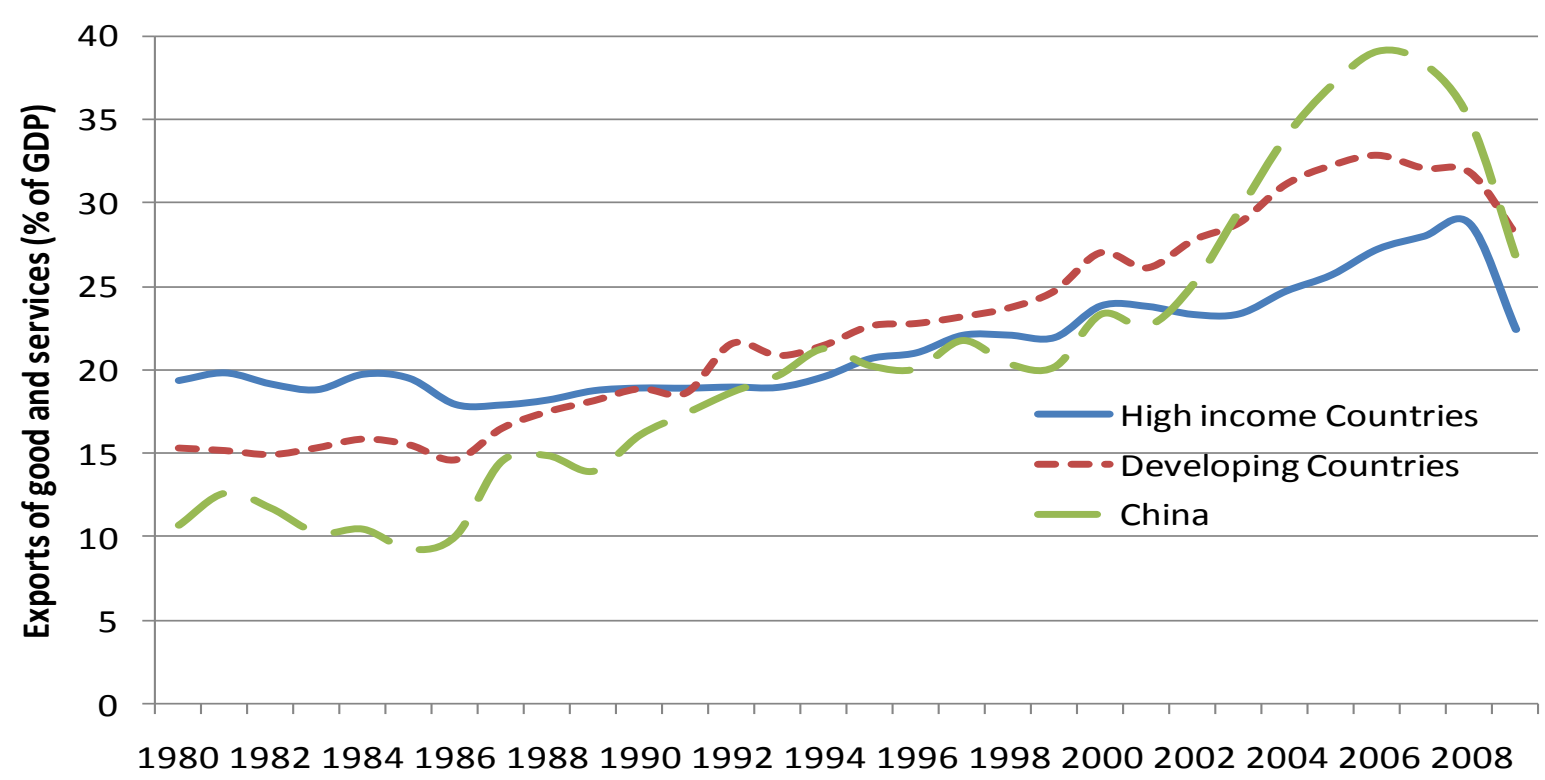

Source: World Development Indicators

It is likely that this increasing globalization is one factor that can be used to explain the high growth rates that developing countries exhibited over the last decade. During the 2000s, developing countries grew on average at 5.6 percent and in 2010, developing countries are estimated to grow at 7.0 percent (World Bank (2011)). In comparison, developed countries grew at only 1.3 percent in the previous decade and in 2010 are estimated to grow at 2.8 percent (see Figure 2a). However, these high growth rates in developing countries mask the vastly different growth patterns of individual economies over the last several decades. 
Figure 2a GDP Growth by Country Group

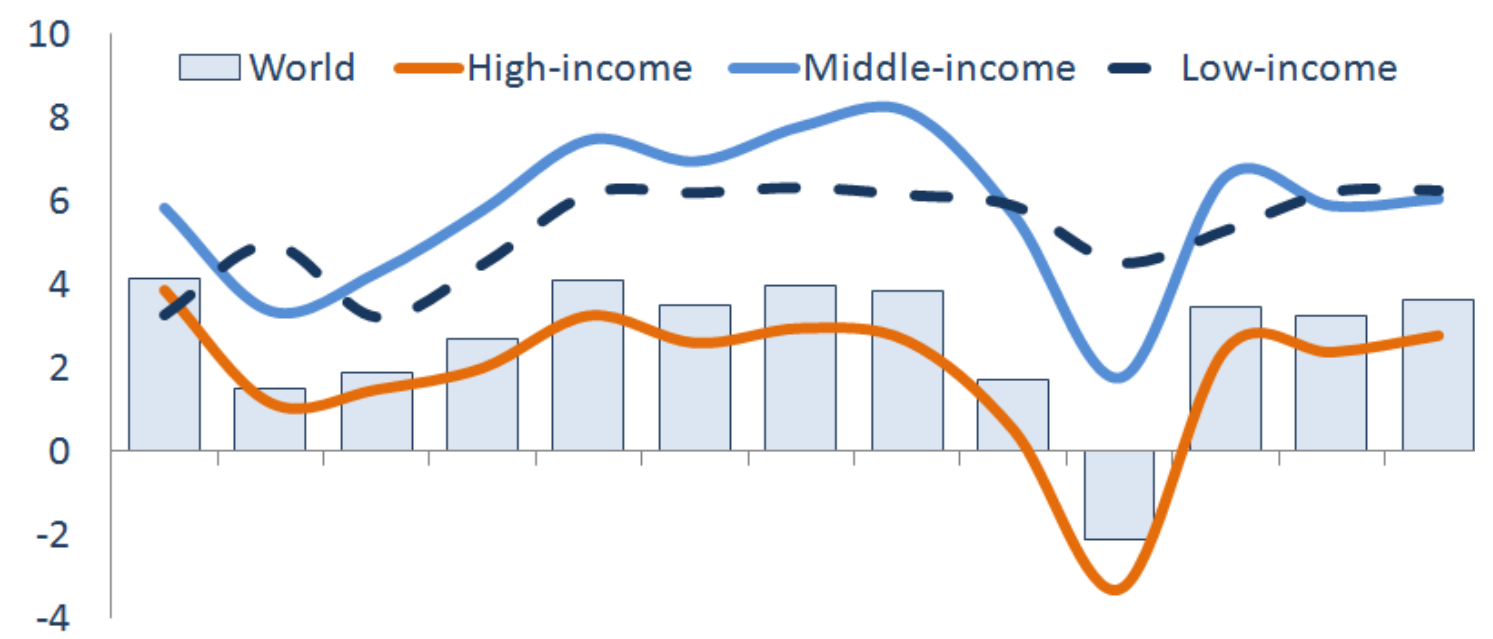

2000200120022003200420052006200720082009201020112012

Source: Global Economic Prospects, 2010

Figure 2b Per capita GDP Growth by Regions

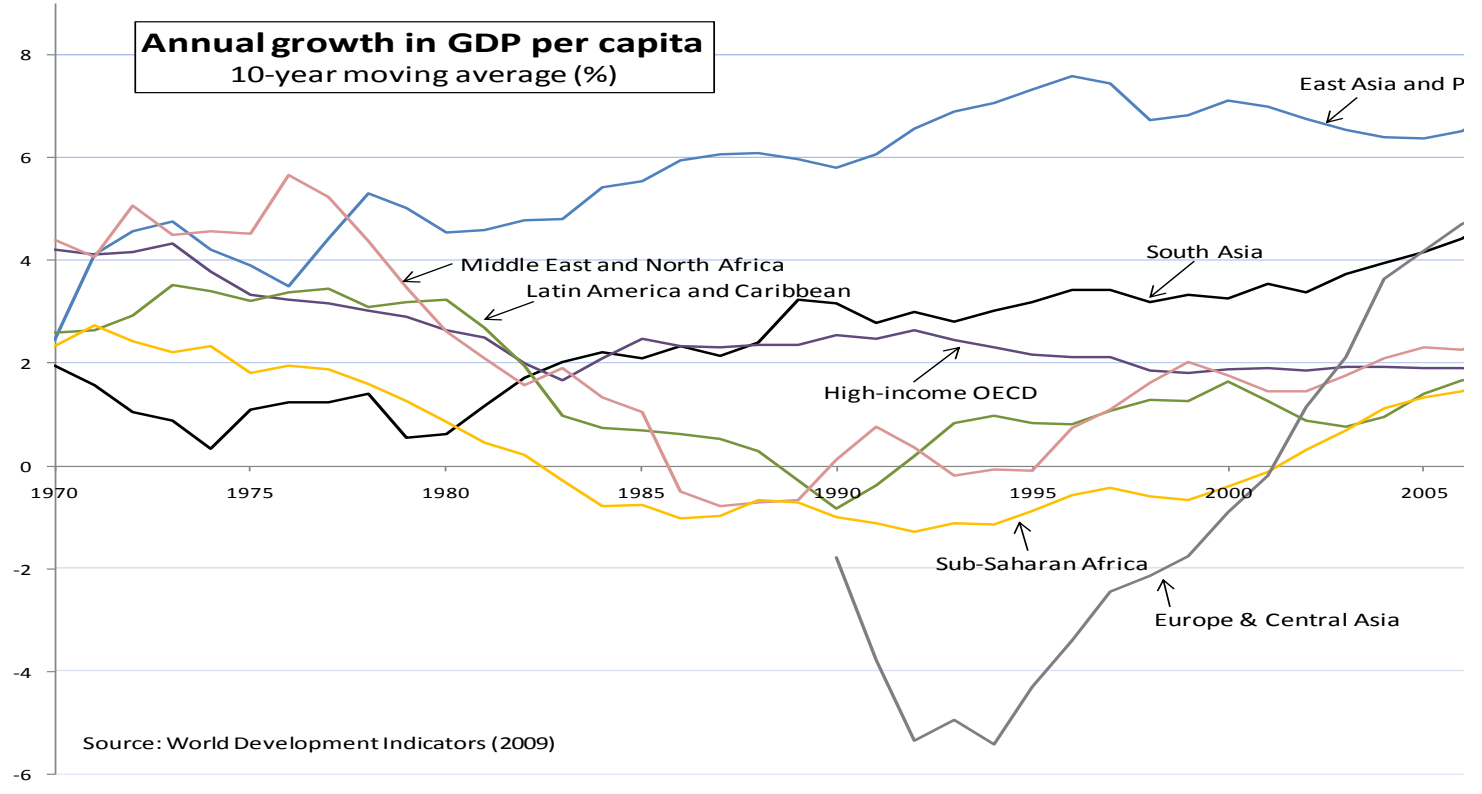

Source: World Development Indicators

Figure $2 \mathrm{~b}$ reports trends in GDP per capita growth over the last forty years across different regions. The figure shows that the regions of East Asia and South Asia grew at higher 
rates, on average, than high income countries for decades prior to the crisis. The gap in growth rates between East Asia and the Pacific, where GDP per capita grew at least 6 percent per year since the mid-1980s, and the rest of the world is remarkable. Yet, by the end of the 2000s, all regions including Sub-Saharan Africa were growing at a faster pace than high income countries in per capita terms.

\section{The Crisis and its Aftermath}

The 2008-09 global economic crisis is possibly the deepest and most complex crisis since the Great Depression. Three primary factors made this crisis unusual in comparison to previous crises. First, the crisis originated in a developed country. Second, many developing countries were able to cushion the effects of the crisis for the most vulnerable groups by increasing or maintaining social spending and safety nets due to strong economic fundamentals prior to the onset of the crisis. Third, and unlike previous crises, developing countries generally fared better and recovered faster than developed countries.

The crisis originated in the collapse of the U.S. subprime housing market after the burst of a major housing boom in 2007 and subsequent fall in the value of mortgaged backed securities (Bordo (2008) and Gorton (2008)). This led to a crisis in the U.S. shadow banking system that quickly spread to European countries through the drying up of interbank liquidity. Although the Federal Reserve, European Central Bank, and the Bank of England all provided liquidity in the fall of 2007, the collapse of Lehman Brothers worsened the crisis and the credit crunch led to a recession in the U.S. and Europe. In the early stages of the crisis, most experts believed that its negative impact would be confined to developed countries. As the crisis progressed, however, developing countries felt the effects through various transmission mechanisms, such as trade, commodity prices, capital flows, and remittances leading to a global downturn (Mishkin (2010)).

However, unlike other crises, developing countries were able to cushion the negative impact of the crisis on output and human development indicators by implementing countercyclical fiscal policies that allowed them to maintain social spending and increase safety nets. The effects of crises on fiscal and household spending depend on the severity of the downturn, government policy, and fiscal flexibility in continuing spending. Empirical evidence on the cyclical response of government spending to the economic cycle shows a different pattern for developing and high income countries. Developing countries tend to have a procyclical fiscal 
policy, reducing spending in a downturn, while high-income countries pursue countercyclical fiscal policy, raising expenditures in a downturn. The latter reflect automatic stabilizers in place as well as discretionary spending to stimulate the economic recovery (Aghion and Marinescu (2007), Talvi and Végh (2000), Perotti (1999), Darby and Melitz (2008), Kaminsky, Reinhart and Végh (2004)).

What it is interesting about this crisis is that developing countries have become more sophisticated at fiscal management, and implemented countercyclical spending by temporarily expanding safety nets, protecting social sector spending, and redirecting fiscal resources to retain social services. This is in sharp contrast to the reaction of developing countries to past crises, in which many countries pursued across the board cuts in government expenditures with little concern for the incidence of fiscal allocation. Therefore, although poverty has increased as a consequence of the crisis, it has increased less than would have been the case otherwise. (World Bank (2010a) and Lewis and Verhoeven (2010)).

Moreover, in contrast to previous crises, the 2008-09 crisis found many developing countries with the required credibility and fiscal breathing space to conduct countercyclical fiscal policy. Among the factors that helped developing countries achieve resiliency to the ongoing economic and financial crisis and be much better prepared to respond to this crisis than more developed countries were higher fiscal surpluses, a better build-up of reserves, lower inflation, and avoidance of currency mismatches which could have led to exchange rate speculation and insolvency (Didier, Hevia and Schmukler (2010a, b) and Frankel and Saravelos (2010)).

Finally, unlike previous crises, developing countries generally fared much better and are recovering more quickly than developed countries. This can be seen in Figures 2a, Figure 3, and Figure 4. Figure $2 \mathrm{a}$ shows that developing country growth rates fell less and recovered more quickly than developed countries. The projected growth rates, prepared by the World Bank Prospect Group within Research, also show systematically higher growth rates for 2011 and 2012 in developing countries. Figure 3 documents the evolution of trade before and after the crisis. Figure 3 shows that developing countries are leading the recovery in trade, with their import demand rising at twice the rate of that in high-income countries in volumes and values. 
Figure 3 Developing Countries are Leading Recovery in Trade

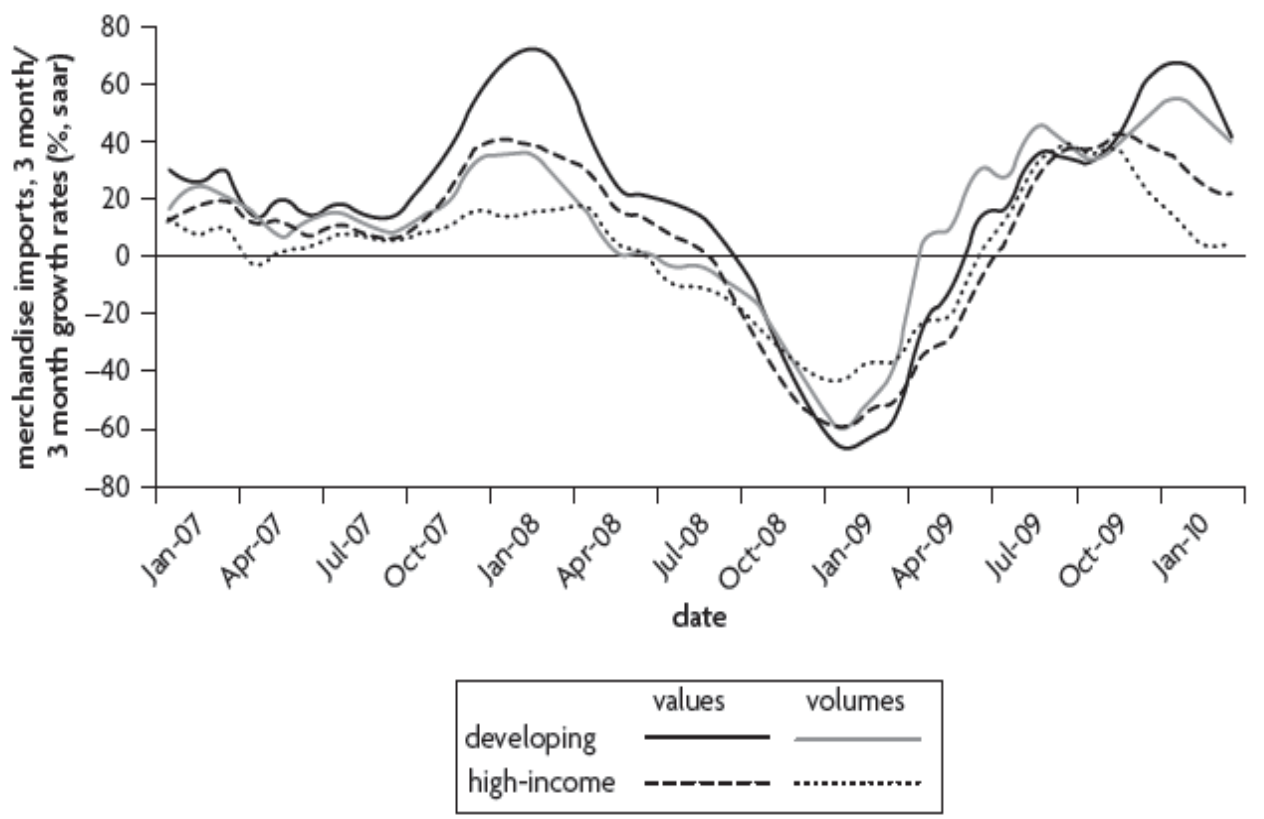

Source: Fardoust, Kim, and Sepulveda (2011)

It is also possible to compare the performance of developing vis-a-vis developed countries in the 2008-2009 crisis relative to previous crises. Figure 4 shows the growth rates for low income countries five years before and five years after the crises in 1975, 1982, 1991, and the current crisis. The low income countries, compared to the rest of the world, were much less affected and are expected to recover much more quickly. This stands in contrast to previous crises, as captured by the solid yellow and black lines, when the low income countries experienced lower growth and recovered less quickly. In this crisis low-income countries are projected to recover more rapidly than in previous crises, with a $\mathrm{V}$-shape recovery path out of the recession (World Bank (2010a)). 


\section{Figure 4 GDP per Capita Growth in Past and Current Crises}

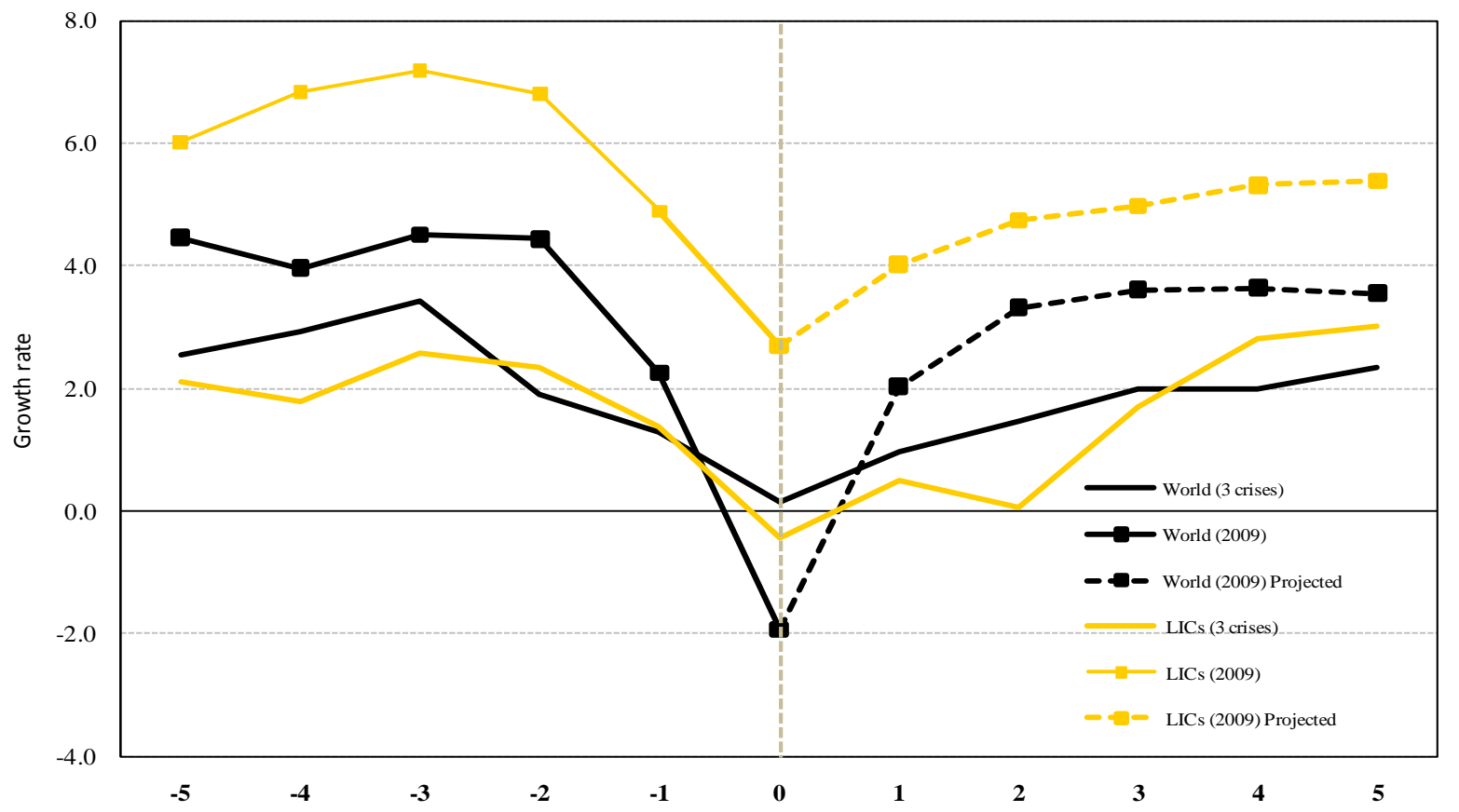

Source: World Bank (2010 a)

Note: The figure plots the average per capita GDP growth in the world and in Low-income countries 5 years before and 5 years after the global crises (centered at zero on the horizontal axis) of 1975, 1982 and 1991, and the current crisis. Also shown in dashed lines are WEO projections until 2013.

\section{The Changing Global Landscape}

The long term shifts in the global economic landscape, as well as the performance of developing countries in the aftermath of the crisis, have cemented the emergence of a multi-polar growth world. Developing countries contributed around 40 percent of global growth in the past decades, and in 2010 their projected contribution will approach 50 percent (see Figure 5). Because developing countries are growing faster, they are also increasing their share in global GDP. Whereas developing country GDP represented approximately 17 percent of global GDP in 1980, as of 2008 that share had increased to 29 percent, when measured at market exchange rates and close to 45 percent if purchasing power parity (PPP) weights are used. Those that are contributing the most to this new global economic landscape are the developing countries that are also members of the G-20; China, and to a lesser extent India, have been the main drivers of these shifts. In 1980, China accounted for 1 percent of global GDP. As of 2008, China's share had increased to 6 percent of world GDP (11 percent in PPP terms), accounting for a larger share 
in the global economy than the economy of Germany or the United Kingdom. India has also emerged as a player, with a 2 percent share in world GDP in 2008, similar to Canada's and Korea's shares. Still other developing countries that represent only a small share of the global economy have experienced a new dynamism and have acted as growth poles in their respective regions. South-South links are also rising rapidly. In 1995 Southern trade was 13 percent of China's total trade; by 2007 it was 28 percent and is projected to reach 50 percent by 2015 .

Figure 5 Almost Half of Global Growth Comes from Developing Countries

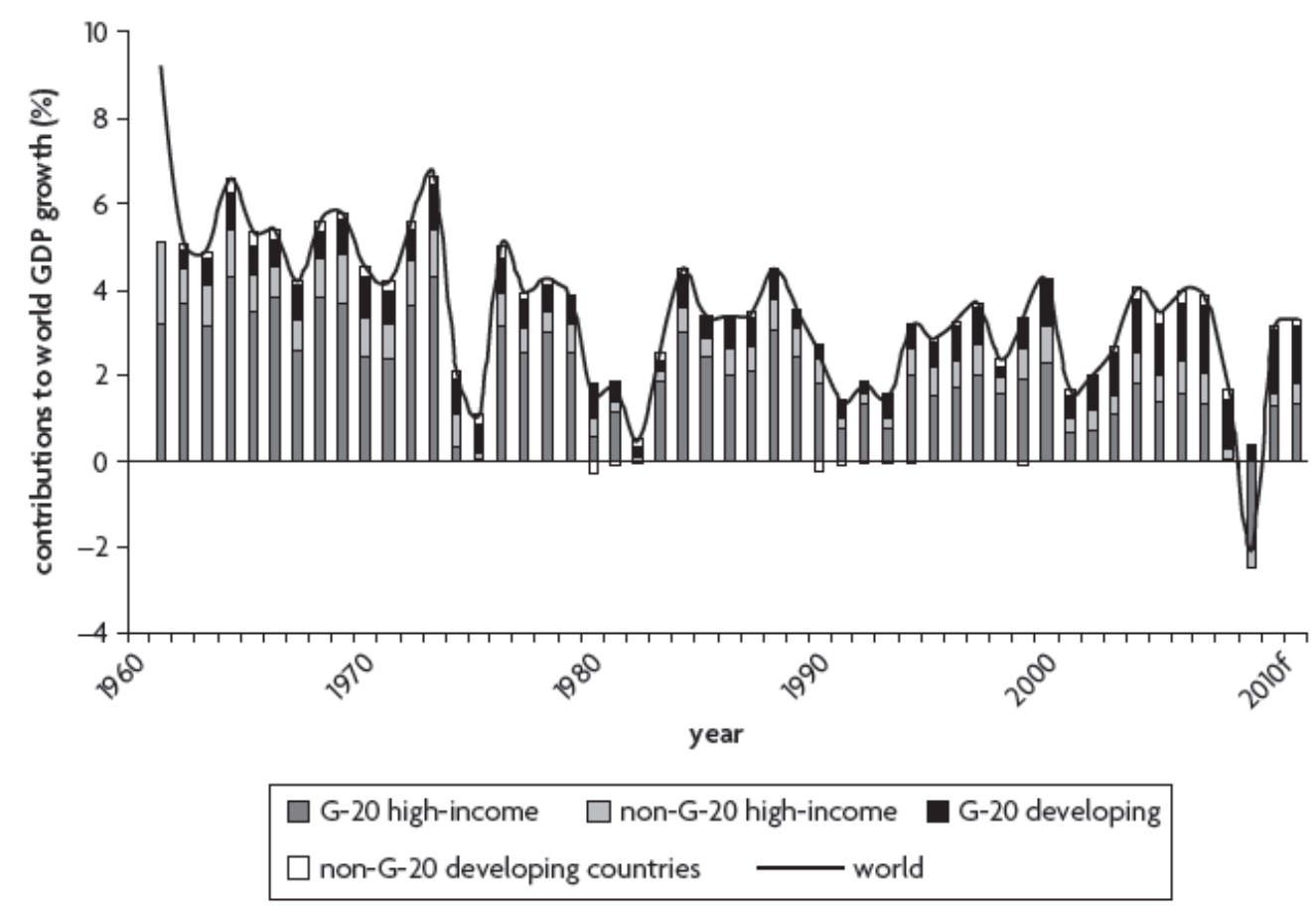

Source: Fardoust, Kim, and Sepulveda (2011)

What do these changes mean for the world? The rapid growth of emerging economies has led to a shift in economic power: forecasts based on analysis by the late economist Angus Maddison suggest that the aggregate economic weight of developing and emerging economies is about to surpass that of the countries that currently make up the advanced world. Longer-term forecasts suggest that today's developing and emerging countries are likely to account for nearly 
60 percent of world GDP by 2030 (OECD (2010)). But it also suggests a return to a world similar to that of 1820. As Figure 6 shows, China and India will be moving to reclaim their importance in the world economy as it was at the beginning of the 19th century when they accounted for about 50 percent of world GDP (Maddison (2007)).

Figure 6 A Return to Normalcy

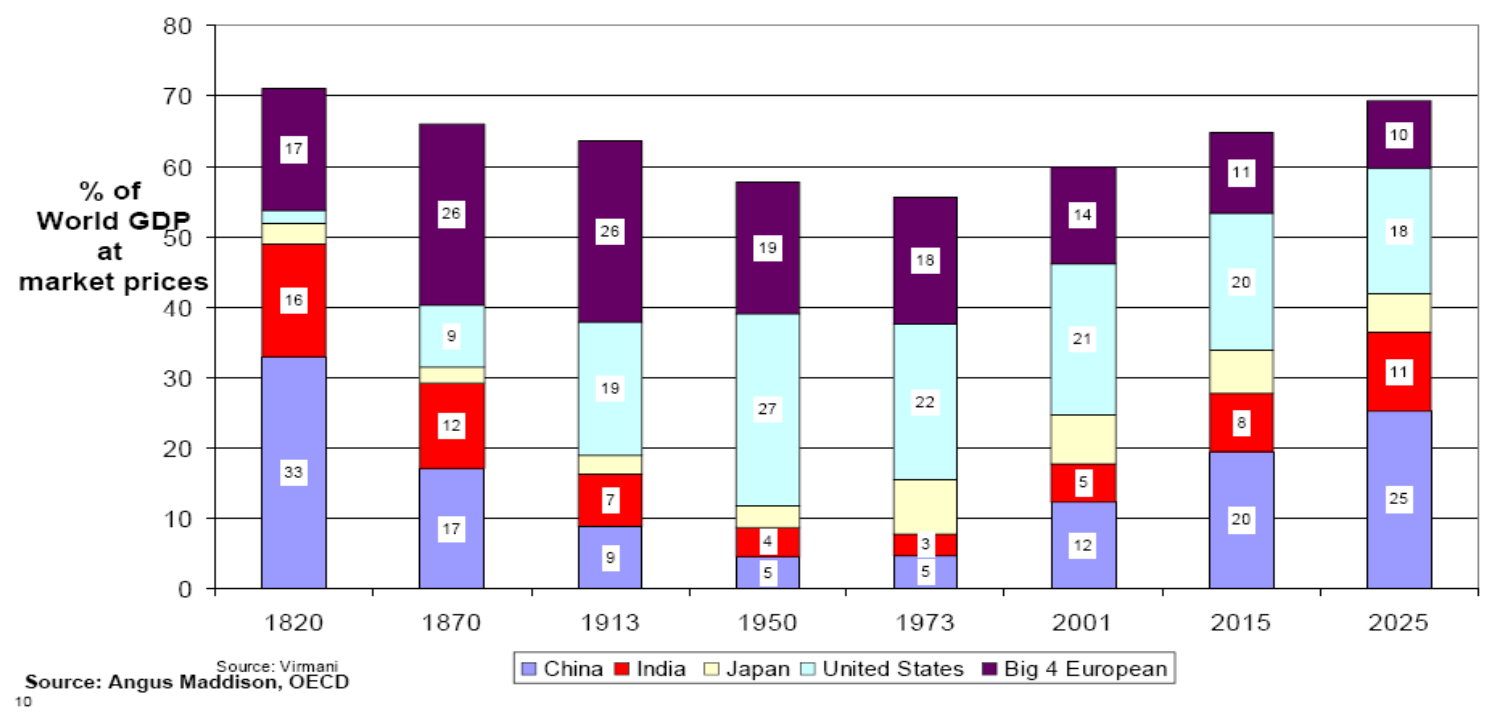

\section{What Can Developed Countries Learn from Developing Countries?}

The development community has engaged in spirited debate over the adequacy of prevailing development frameworks. Some feel that developing countries are recovering rapidly in part because they have followed orthodox policies. Others point to the high economic and social costs of the crisis and the difficulties encountered by countries that have followed such policies but nevertheless cannot succeed in moving into middle or upper income status. Some countries appear to have done well with policies that involve a more active role for the state than envisaged by the Washington Consensus. China's active efforts to solicit and encourage foreign investors through tax holidays are a case in point (Du, Harrison, and Jefferson (2011)). We are also seeing that pro-poor social policies, such as better education and health services for poor people and certain transfer schemes, can help assure more equal access to the opportunities unleashed by market-driven development. However, here too progress has been uneven, with governance problems plaguing efforts to deliver better services to poor people. 
Different periods of history have been associated with the rise and fall of different schools of thought in economics. Keynesianism was popular in the 1930s and 1940s, the neoclassical tenets of Milton Friedman and others reached ascendance in the 1980s. In development circles, the Washington Consensus was popular into the 1990s. But now we are asking ourselves how we can go beyond the Washington Consensus. Policymakers and researchers looking at this new global landscape are asking whether development economics in its present form is well positioned to tackle the most urgent issues of the day and whether developed countries can learn from the emerging economies ascent.

The 2008-09 crisis has made the need to rethink development economics only more compelling and some of the lessons learned are most relevant for developed countries. The World Bank's president summarized the preliminary lessons and key researchable questions going forward in speech he gave at Georgetown University in September 2010. The speech drew on a document prepared by Alan Gelb, Ann Harrison, and Martin Ravallion, "New Research Directions"(World Bank (2010b)). The document suggested that new research directions should focus on four broad topics: economic transformation, broadening opportunities, mitigating risk, and focusing on result. We refer to this as the TORR agenda. We need to better understand how economic transformation happens; how to broaden opportunities to ensure that all individuals can participate in the benefits of, and contribute to, such transformation; how to deal with the emerging new global challenges related to risk and vulnerability; and finally, to assess the effectiveness and results of development efforts, including external assistance.

\section{Securing Transformation}

Why have few countries been able to achieve sustained growth, while others appear to remain trapped in poverty? The Commission on Growth and Development (2008), led by Michael Spence, Roberto Zagha and others, identified 13 countries that were able to maintain high sustained growth over 25 years in the postwar period. ${ }^{3}$ One insight of the Growth Commission report rests in the observation that countries that have made the transition from low income to middle or high income countries have sustained high investment-to-GDP rates (both private and public investment). These differences are shown in Figure 7. By investing resources,

\footnotetext{
${ }^{3}$ The Commission on Growth and Development report identified 13 success stories of sustained high growth: Botswana, Brazil, China, Hong-Kong (China), Indonesia, Japan, Korea, Malaysia, Malta, Oman, Singapore, Taiwan (China), and Thailand.
} 
rather than consuming them, economies make a trade-off between present and future standards of living. If the sustained, high-growth cases are any guide, it appears that overall investment rates of 25 percent of GDP or above are needed to achieve growth rates of this magnitude. In addition these 13 countries often invested at least another 7-8 percent of GDP in education, training, and health.

Figure 7 Investment to GDP Ratios. Selected Countries and Growth 13

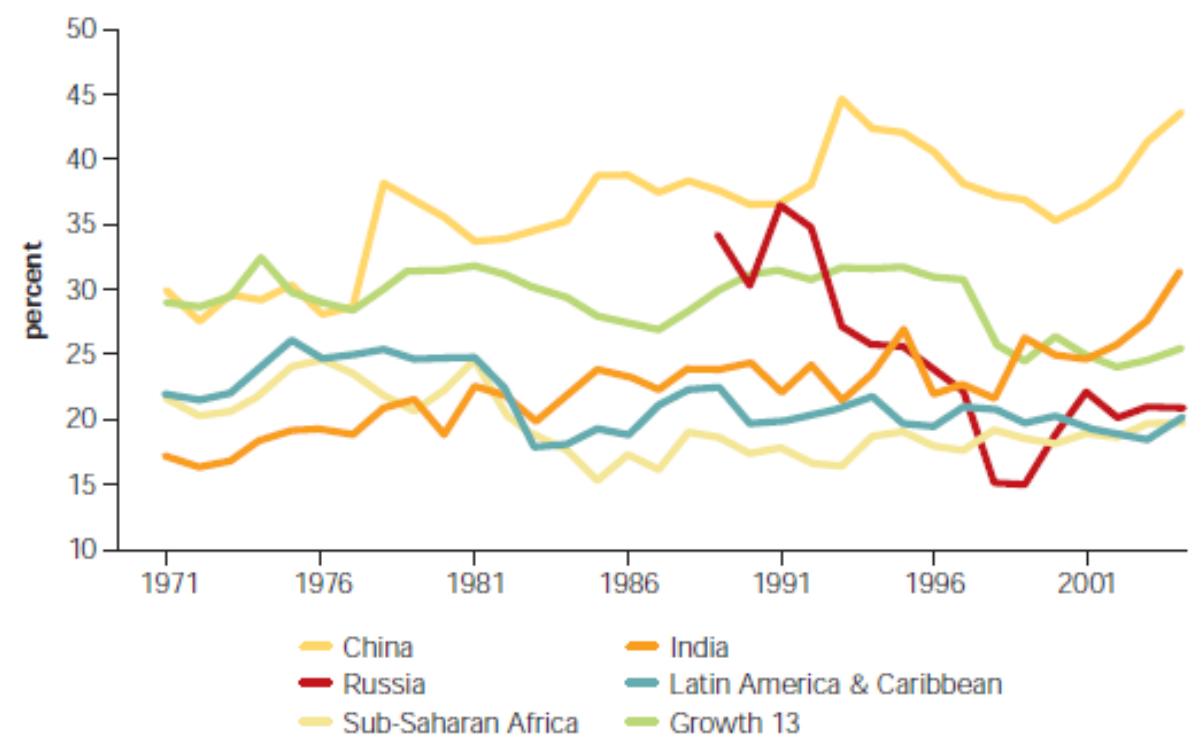

Source: Commission on Growth and Development (2008)

To address this fundamental question of why so few countries have sustained high rates of growth requires a deeper understanding of the process of how an economy's structure evolves over time. This is not just about the shift from agriculture to industry and services. This question is about the dynamics within micro-foundations of economic growth. Within agriculture, services or industry how does the process of moving into higher-quality goods and services happen? Within firms, why are some able to move into export markets and start producing new goods, while others languish? How do economies move into information technology and services? What determines a country's economic structure and what contributes to the diversification in an economy? How do firm and industry dynamics — entry, exit and the allocation of resources across firms within sectors and across sectors-contribute to efficiency? Why do certain firms and industries achieve more growth than others, given the same inputs? 
Important questions related to this agenda are the respective responsibilities of the market, the state, and the private sector in sustaining the dynamics of structural change. What roles do markets and states play in the transformation? How do political economy and governance factors constrain the scope for effective public action in promoting structural transformation? What should be the role of infrastructure, and who should provide it? The answers may vary, depending on political leadership and the ability of governance structures to withstand capture by powerful elites. However, all successful countries have used market signals and international competition as the fundamental mechanism for resource allocation. For example, in Figure 1 we documented the increasing importance of trade in the integration of developing countries into the world economy.

In addition to heeding market signals, however, successful countries have also recognized that the state has a role to play in the transformation process. The role of the state in promoting certain patterns of industrial development has been a highly contentious subject in politics and economic research. Most governments attempt to promote industry, yet evaluations of their interventions have been few and rarely rigorous. There is a pressing need for new research efforts to evaluate these policies. It would be misleading to make general policy prescriptions for successful economic transformation based on the success of a few countries with particular policies and against a particular national backdrop. In many of these example cases, the government played a strengthened role in infrastructure provision, skills development, and creating an enabling regulatory framework. For example, instead of using blanket subsidies to promote exports and attract FDI, the government of China has given companies tax incentives and provided infrastructure for special economic zones in key sectors like electronics and telecommunications to attract multinationals.

The key challenge is how to design policies that are most effective in achieving structural transformation and diversification by successfully promoting winners, not losers. Harrison and Rodriguez-Clare (2009) distinguish between "soft" industrial policy, whose goal is to develop a process whereby government, industry, and cluster-level private organizations can collaborate on interventions that can directly increase productivity and "hard" industrial policy that can distort prices. Their idea is to shift the policy design to interventions that deal directly with the coordination problems that keep productivity low in certain sectors. Thus, instead of tariffs, 
export subsidies, and tax breaks for foreign corporations, they suggest focusing on programs and grants to help particular clusters by increasing the supply of skilled workers, encouraging technology adoption, and improving regulation and infrastructure, for example. While "hard" industrial policy is easier to implement than "soft" industrial policy measures, tariffs and subsidies more easily become entrenched and are more subject to manipulation by special interest groups.

Lin (2010) and Lin and Monga (2010) argue that policies that target activities which are "comparative advantage facilitating" (CAF) type are the most successful in contributing to structural transformation. Governments should not target production activities that are not aligned with the country's comparative advantage. Public policies should be of the "comparative advantage facilitating" (CAF) type, helping to solve and overcome the problems of coordination and externalities that beset processes of structural transformation and innovation.

\section{Broadening Opportunities}

There is also a need to better understand how to broaden access to economic opportunities to ensure rapid poverty reduction and promote human development. Inequalities of opportunities lie at the heart of inequitable growth processes. Atkinson, Piketty, and Saez (2011) have documented the evolution of inequality of opportunities by looking at the top income shares over the long run for more than 20 countries using income tax statistics. They found that in the last 30 years top income shares increased substantially in English speaking countries, China, and India (Figures 8a and 8b). They attribute this increase in part to an unprecedented surge in top wage incomes. Broadening opportunities is as relevant for developing countries as it is for highincome countries. 
Figure 8a Rising Inequality in Developed Countries (Top 1\% Share 1920-2005)

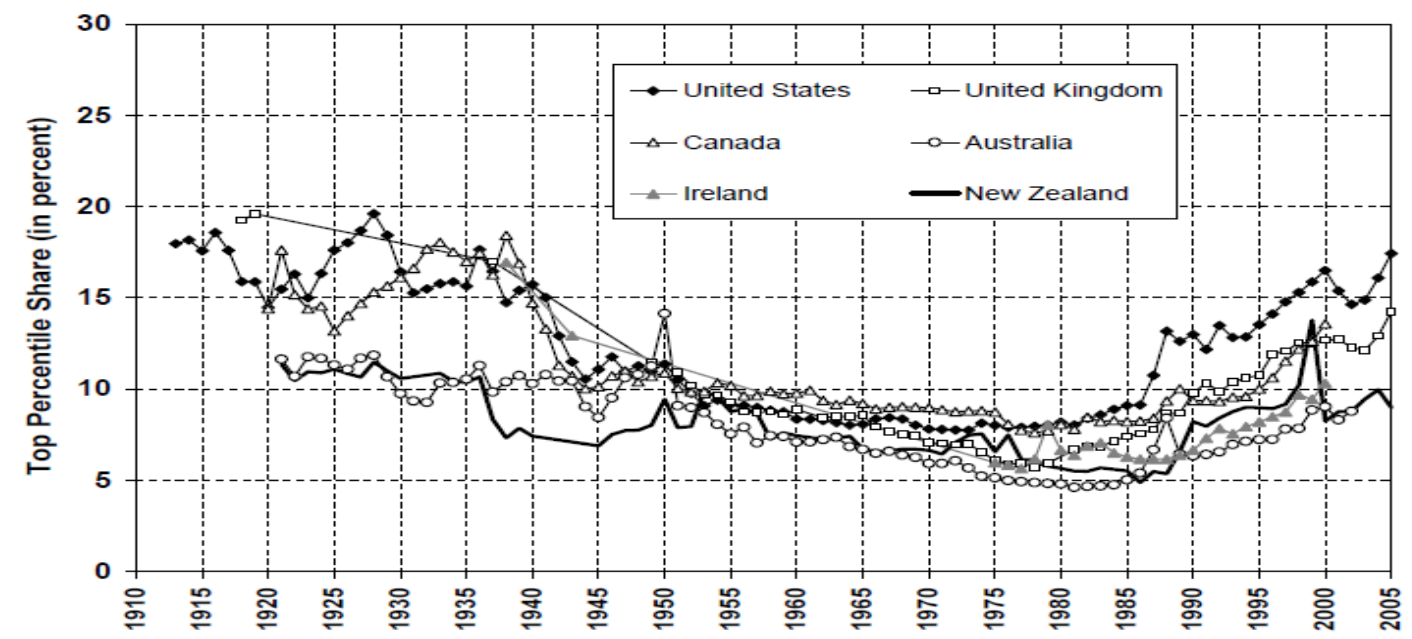

Figure 8b Rising Inequality in Developing Countries (Top 1\% Share 1920-2005)

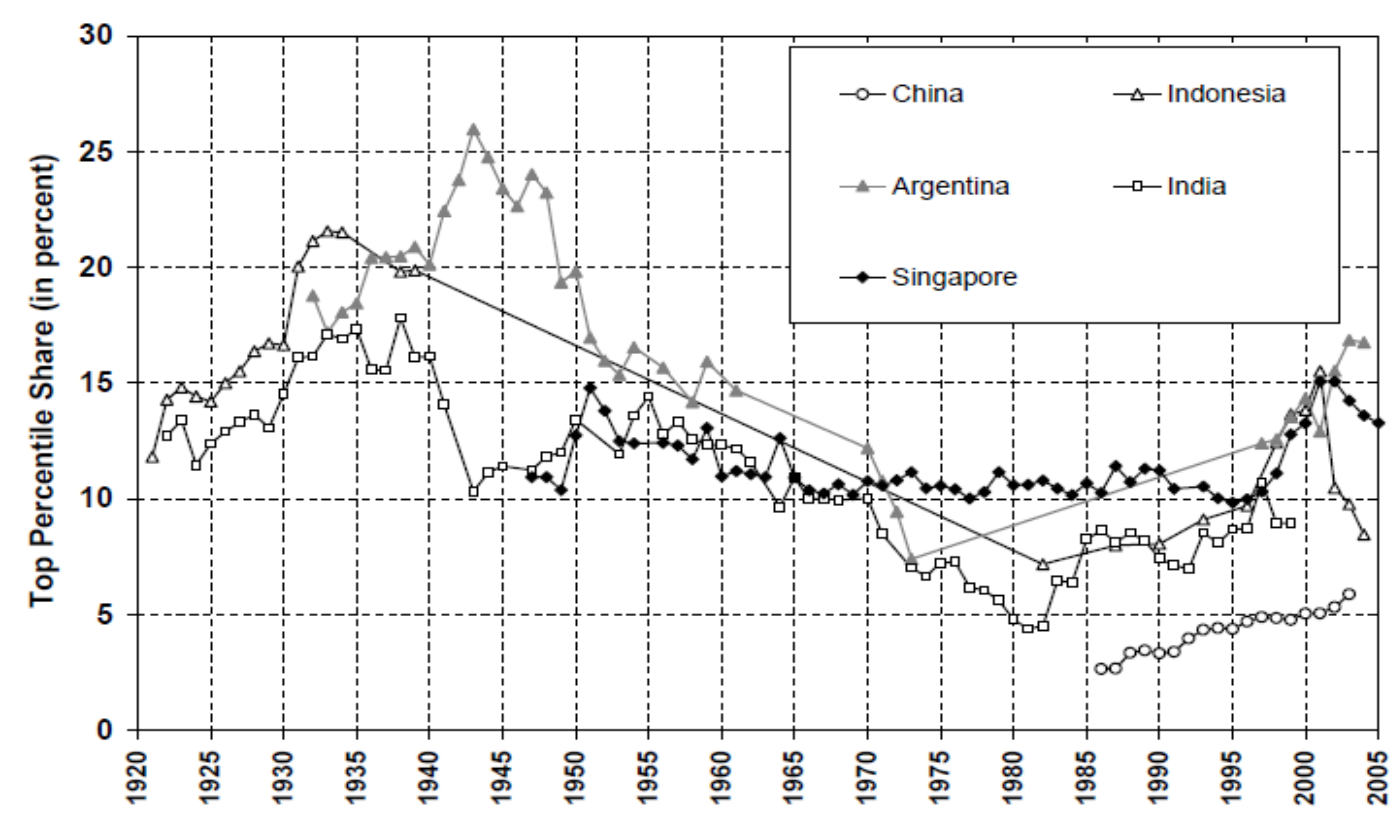

Source: Atkinson, Piketty, and $\underline{\operatorname{Saez}(2011)}$

How can policymakers ensure that the benefits of growth are shared in an increasingly unequal world? Lack of access to opportunities, particularly for investing in education, health, and other forms of human capital, hold back growth and makes the growth that does occur less effective in reducing poverty and inequality. Ensuring better services for poor people is one key 
element. However, across countries, social outcomes are only weakly related to spending in social sectors and, in many countries, additional spending on social services is subordinated to other priorities. Understanding why similar programs work better in some countries than others and identifying the binding constraints to better service delivery are key questions to improve access to opportunities.

Governance plays a role in explaining the inadequacy of services to the poor. Past research has documented large-scale job absenteeism and poor on-the-job performance by frontline service providers. Reforms to improve provider incentives frequently face substantial political opposition, because improving the quality of service delivery is not as politically popular as the provision of protected jobs or price subsidies. Too often front-line service providers and political decision makers have weak incentives to improve services. Publically documenting and understanding these deficiencies in service provision are key to achieving better services. One intervention of this nature focused on using information to train and mobilize local community agencies in India with legal powers to improve the village public school. While this did not have any direct impact on the public school system, it did succeed in stimulating large scale private volunteer teaching which improved literacy levels dramatically. Building on these findings, civil society organizations in Africa and India are experimenting with making local information more available to politicians by disseminating public service performance indicators at the level of electoral constituencies.

Another important area for development economics research is on gender equity, the focus of the World Bank's World Development Report 2012. Gender disparities in rights, access to resources and economic opportunity, and in voice and political participation vary across and within countries, but remain pervasive worldwide. On the one hand, more rapid development can help attenuate gender disparities. In the other direction, reducing gender inequality can help improve development outcomes. There is increasing awareness of the costs that gender disparities impose on individuals and societies, and of the resulting implications of these inequities for development prospects.

However, there are still large knowledge gaps in how and why gender equity matters for development and in the understanding of how best to take account of and address gender differences in policy design. As Figure 9 shows, these questions are complex to tackle, even in 
developed countries where equality of opportunity in education has improved, but there are still large discrepancies in outcomes. Figure 9 is taken from Bertrand, Goldin, and Katz (2009), who present evidence on how career dynamics differ by gender for MBAs who graduated between 1990 and 2006 from a top U.S. business school. Although male and female MBAs present early identical (labor) incomes at the outset of their careers, their earnings soon diverge, with the male annual earnings advantage reaching almost $60 \log$ points at ten to 16 years after MBA completion. Three reasons have been identified by the authors for the large and rising gender gap in earnings: differences in training prior to MBA graduation; differences in career interruptions; and differences in weekly hours. Disparities in the productive characteristics of male and female MBAs are small, but the pecuniary penalties from shorter hours and any job discontinuity are enormous for MBAs.

Figure 9 Male and Female Median Annual Salaries by Years since MBA

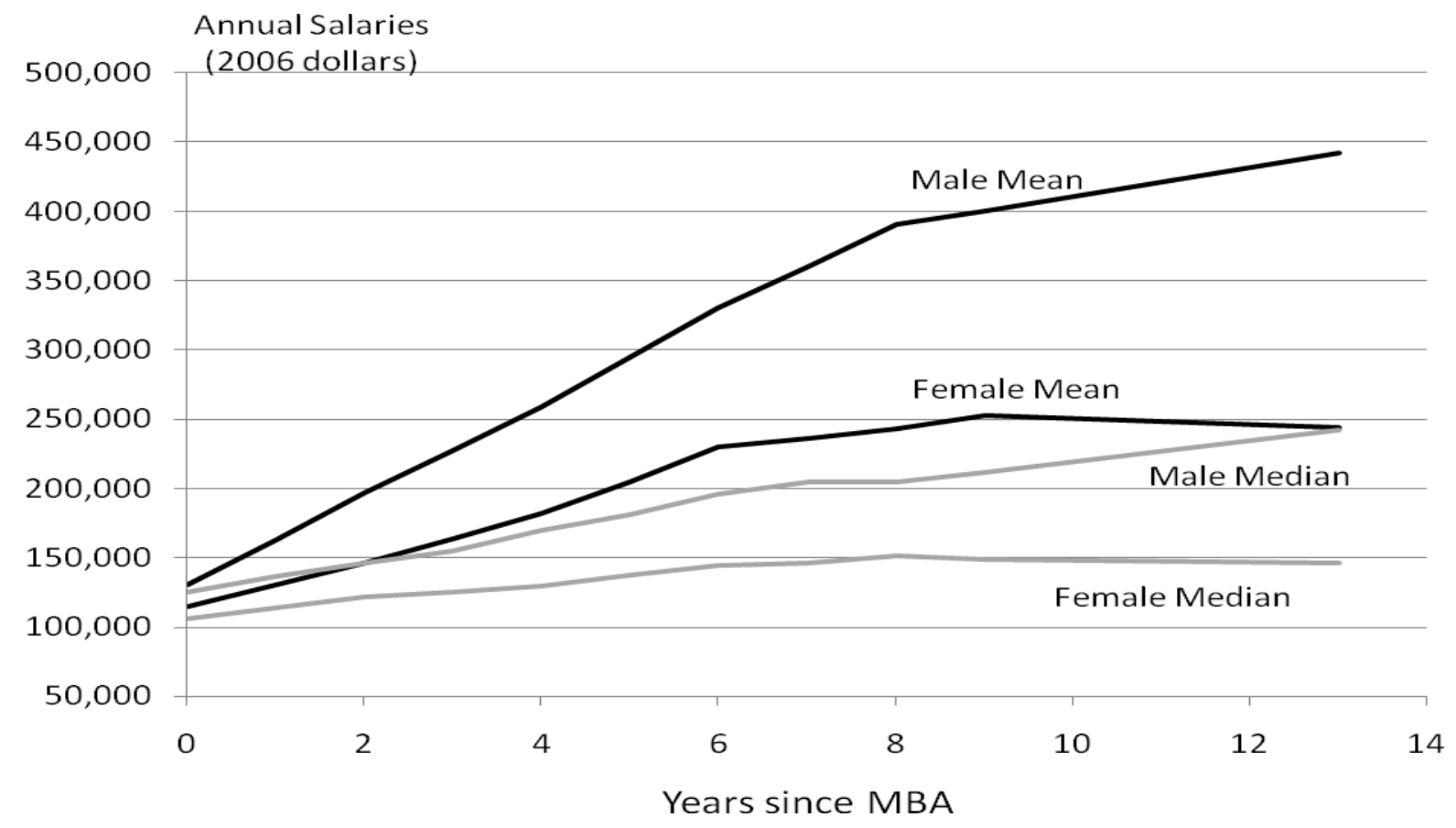

Source: Bertrand, Goldin, and Katz (2009)

Broad access to financial services is also crucial for inclusive growth. There is a need to assess and evaluate the channels through which access to finance can contribute to more propoor growth processes, such as promoting entrepreneurship, innovation, and technology adoption. The role of financial literacy and gender differences should also receive greater attention. Ultimately, the aim should be to evaluate the impact of firms' financing constraints and 
households' inability to access financial services on economic growth and poverty alleviation, and to better identify different ways to improve access, ranging from microfinance innovations to making improvements in the functioning of mainstream financial institutions and systems. For example, one frequently used policy for improving micro-, small-, and medium-size enterprises' access to bank loans is creating a credit guarantee scheme that insures banks against borrower default. However, there is very little rigorous evidence on the impact of these schemes that can guide policy discussion.

\section{Managing Risk and Vulnerability}

Recent natural disasters (such as earthquakes and tsunamis), health pandemics, wars and civil strife, the oil and food price shocks of 2007-08, and the global economic crisis of 2008-09 have reminded us that the world is a risky, interconnected, and sometimes fragile, place. Moreover, recent history has confirmed that a large fraction of the developing world's population remains particularly vulnerable to these shocks. Developing countries are assessing how the most recent crisis will affect their near-term growth prospects and how they can better protect themselves going forward against current and prospective risks.

In the area of natural disasters - extreme weather events such as cyclones, floods, and earthquakes - research in Bangladesh has highlighted the success of relatively simple and costeffective protection measures, such as providing emergency shelters large enough to accommodate family members and their livestock, which counteracts households' tendencies to remain in the path of a disaster to protect the bulk of their wealth. Other work on disaster preparedness has emphasized the need for regulatory reform, as well as new regulations to lower hazard exposure. For example, land use regulations to limit settlements in flood-prone areas are often difficult to enforce; reform of commercial building codes and regulations, on the other hand, may help to reduce housing shortages and provide stronger price signals to housing suppliers for improving quality and safety.

Another important area for research is the establishment of social safety nets at reasonable costs. Safety nets for the poor are sometimes seen as harmful, or at best neutral, to economic growth; however, recent research has suggested that some of these traditional concerns need to be reconsidered. Past work has focused on the problem of avoiding "leakage" to the non- 
poor and given too little attention to other issues, including assuring better coverage, maintaining incentives for escaping poverty by other means, and devising social protection policies that can act as automatic stabilizers in times of crisis. Such stabilizers do not require long lead times to provide help and do not inhibit access for those in need. Furthermore, the establishment of safety nets does not necessarily mean "better targeting," which can come at (often hidden) costs, including to poor people. The scope for nongovernmental partnerships in social protection has also been under-emphasized in the research community. Developed countries have already learned from safety nets solutions founded in developing countries and transferred to rich ones as is the case of the Mexico's 'Oportunidades' program.

Most countries, including those that have experienced rapid development success underpinned by financial deepening, have suffered from financial crises interrupting the growth process, and sometimes setting back progress for a decade or more. Heightened risks at the level of the individual firm and households have reinforced the role of financial instruments and markets for hedging and managing risk at the micro level. Risk management, including crisis prevention, needs to become a central part of the research agenda on financial development. Building on past work, further effort is needed to investigate the impact of supervision strategies as well as the impact of compliance with Basel Core Principles on bank stability, the interaction of bank insolvency resolution and deposit insurance policies, and the impact of financial globalization on bank efficiency and access to financial services.

Another important sub-theme concerns how to better utilize and protect various aspects of the global commons in a growing and rapidly urbanizing world. While globalization has been a potent force for development, the recent financial and economic crisis has exposed the fragility of growth to policy failures, the spillover effects of shocks between developed and developing countries, and the global interconnectedness of natural resources. Figure 10 shows that globalization has increased the transmission of global shocks to local economies. While industrial production was not closely linked in Mexico and the United States prior to the formation of NAFTA, after its formation movements in industrial production between the two countries became closely aligned. The increasing interconnectedness of economies through trade and capital linkages must be used to promote shared growth, and means must be found to address the greater risk associated with greater exposure to global shocks. 
Figure 10

Industrial Activity Index in Mexico and USA, 1980-2009

(Seasonal Adjusted Data, Mexico 1993=100, USA:1994=100)

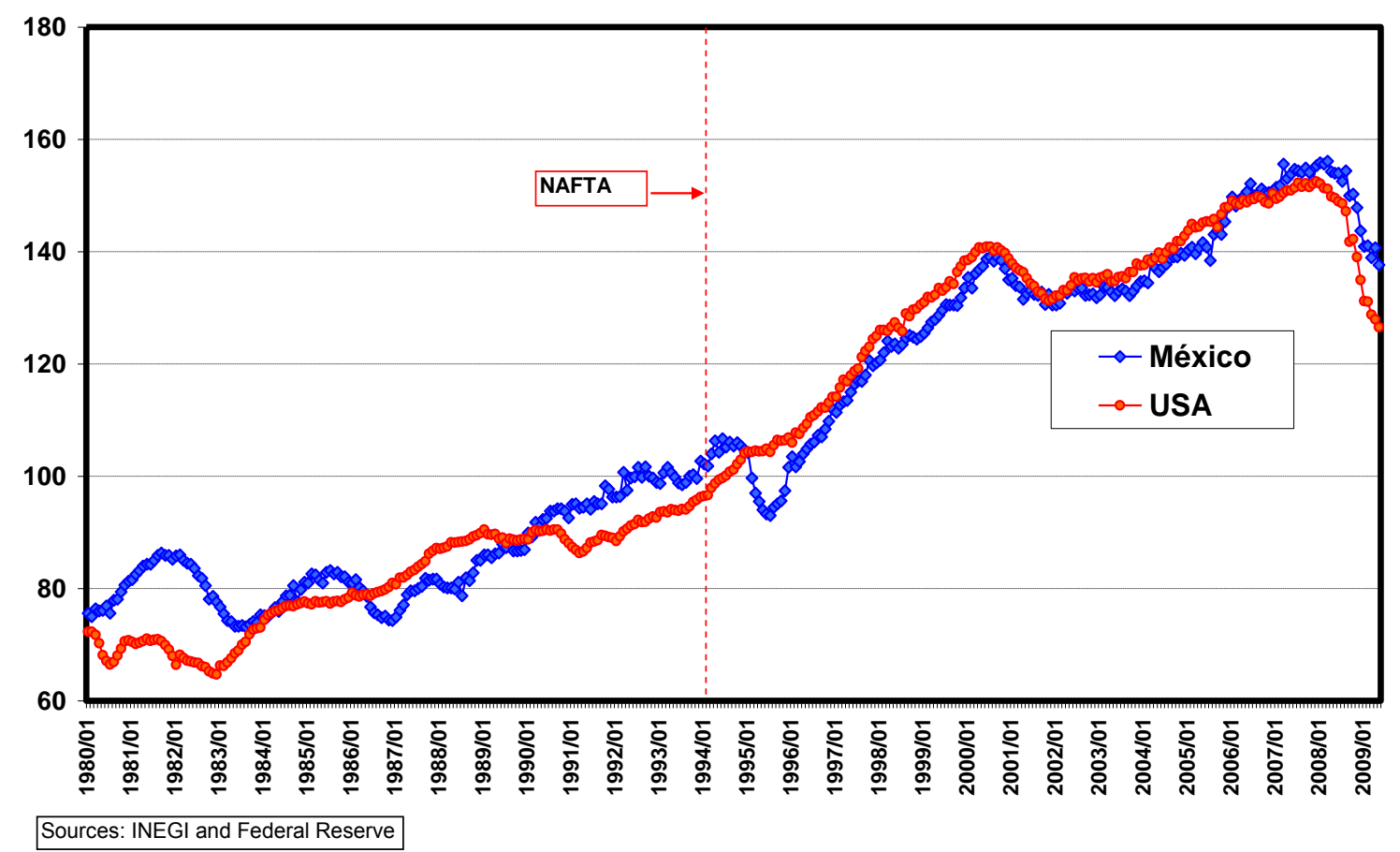

Source: Esquivel (2011)

Economic growth also places increasing pressure on common resources like the environment. Given demographic imbalances between countries, and the threat of larger-scale environmental disruptions in the future, migration also looms as a growing issue. How should global arrangements be reformed to ensure that these challenges are widely seen as important and legitimate, and that international responses provide a robust and supportive framework for sustainable development?

New challenges can also be expected for food security. Demand for food is expected to grow substantially over the next half-century in response to population growth and rising incomes, especially among the large and populous emerging economies. Agricultural productivity growth is needed, given constraints on the use of additional land or water, but in recent decades productivity growth appears to have slowed, in part because of past cutbacks in support for public agricultural research and development. Further sharp spikes in food prices, as in 2007-08, are expected when adverse shocks coincide with low stock levels. One of the 
emerging lessons of the 2007-08 food price spike is that even though market prices do not always work, misguided intervention can make things worse, as witnessed by the impact on wheat prices of the announcement on an export ban on wheat by Russia in August 2010 shows (Figure 11).

Figure 11 Wheat Daily Prices

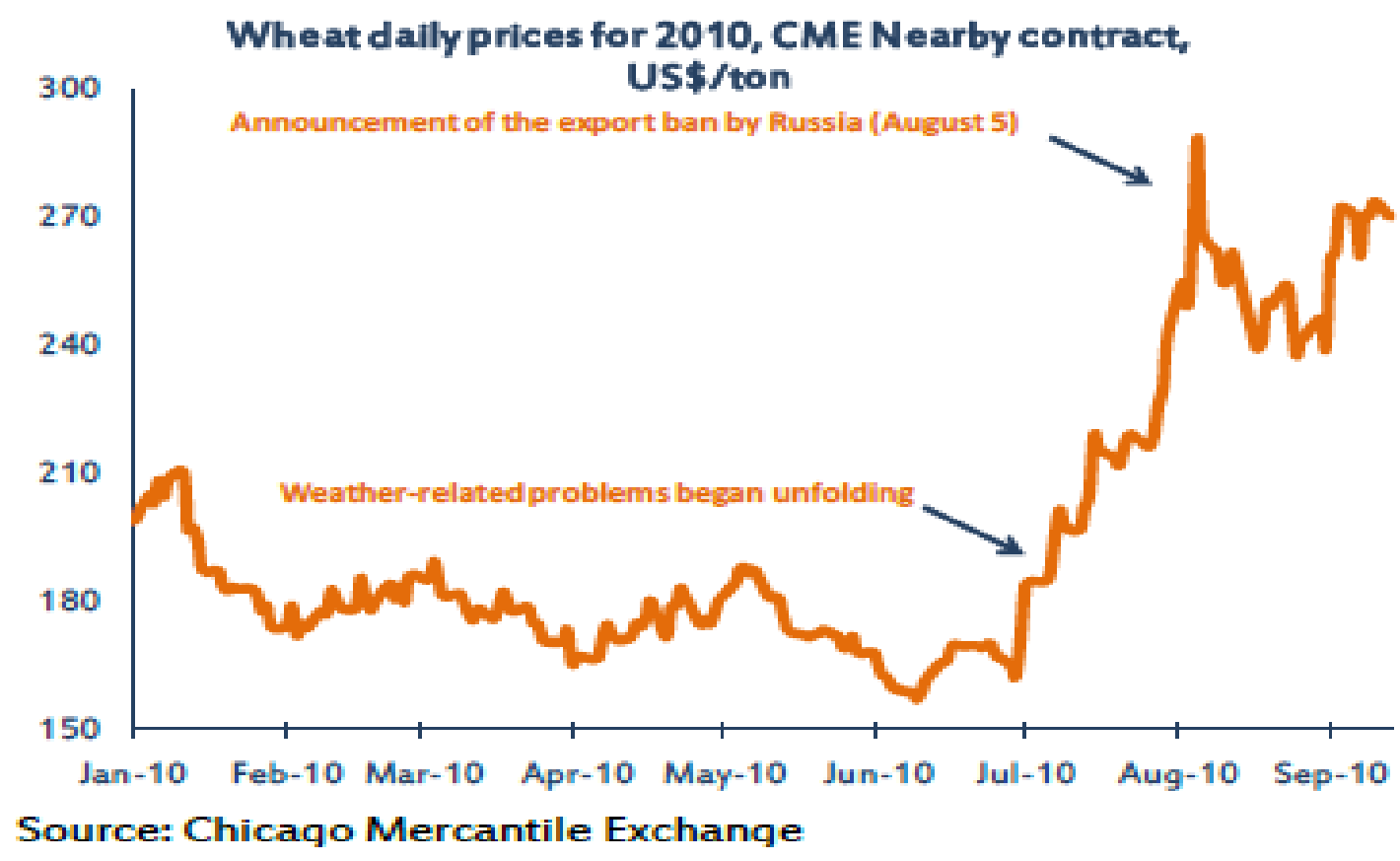

Source: World Bank (2010c)

\section{Knowing What Works and Does not: The Results Agenda}

The development community is increasingly focused on results. How should evaluations be conducted and how can delivery mechanisms be improved to generate better results? What innovative roles can public-private partnerships provide? How can development loans and aid avoid undermining accountability mechanisms in recipient countries, and promote rather than discourage policy reform? Aid and loans, whether stemming from public or private sources, are not the main drivers of development success. The dominant role has to be played by the populations and governments in the countries concerned. One example is China's mode of economic reform in which partial reforms are implemented in an experimental manner and 
expanded upon proven success, as was the case for SOE reform in which private firms gradually increased their participation in the workforce through joint venture activities (Figure 12).

Figure 12 China Workforce by Firm Type

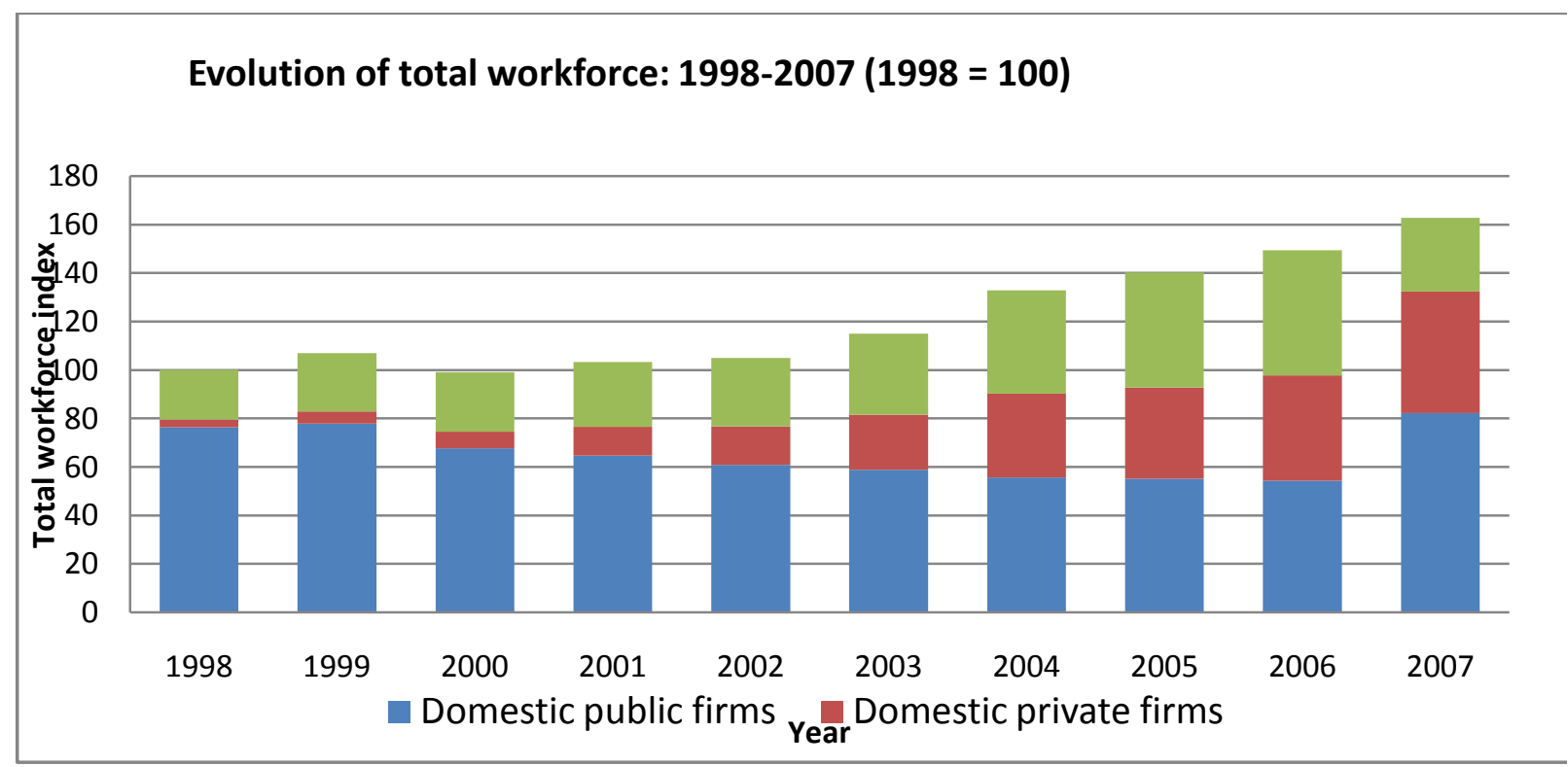

Source: Du, Harrison, and Jefferson (2011)

The ability to learn from country experiences rests heavily on the quality of those data collected. There is still much work to be done in improving these data, such as in reducing comparability problems, understanding data inconsistencies, reducing biases in data collection, and better linking across types of data. At the macro level, research has long had an important role in creating the tools, especially the data, needed for monitoring overall development effectiveness at country and sub-national levels. At the micro level, credible evaluations of development policies and projects (both ex ante and ex post) are accompanied by continuing methodological and data-related challenges. Methods will vary depending on the nature of the interventions that are being studied. There have been important advances in the use of both experimental and non-experimental evaluation methods for assigned programs (meaning that some observational units get the programs and some do not). However, these tools can be misleading for informing development policy (including scaling up) and may not be appropriate 
for many of the most important questions we face in development policy making, where the intervention is not assigned or its assignment entails large spillover effects.

\section{Conclusions}

This essay presents empirical evidence of the better growth performance of developing countries before and after the 2008-09 economic and financial crisis and how this better performance has led to a changed global economic landscape in which developing countries are taking center stage as multiple growth poles emerge. Nevertheless, against this backdrop it is important to acknowledge that this paper has not addressed issues like global imbalances, decreasing aid budgets, and trade protectionism, among others, that may influence the growth and development of developing countries in the future.

We also present a new research framework for development economics that highlights key topics to be addressed, and critical researchable questions, which can offer lessons to developed countries. This new framework encompasses four areas we refer to as the "TORR" agenda. First, Transformation, that is, what underlies structural changes? Second, Opportunities, how can it be ensured that the benefits of growth are shared by all? Third, how can countries manage the Risks associated with environmental, trade, and financial shocks? Fourth, the profession must orient its policy prescriptions around a new focus on Results and aid effectiveness. 


\section{References}

Aghion, Philippe, and Ioana Marinescu. 2007. "Cyclical Budgetary Policy and Economic Growth: What Do We Learn from OECD Panel Data?" NBER Macroeconomics Annual 22: 251278.

Atkinson, Anthony B., Thomas Piketty, and Emmanuel Saez. 2011. "Top incomes in the long run of history." Forthcoming Journal of Economic Literature 49(1):3-31.

Bertrand, Marianne, Claudia Goldin, and Lawrence F. Katz. 2009. "Dynamics of the gender gap for young professionals in the financial and corporate sectors." NBER Working Paper Series 14681, NBER, Cambridge, MA.

Bordo, Michael D. 2008. "An historical perspective on the crisis of 2007-2008." NBER Working Paper Series 14569, NBER, Cambridge, MA.

Commission on Growth and Development. 2008. The Growth Report: Strategies for Sustained Growth and Inclusive Development. Washington, DC: World Bank.

Darby, Julia, and Jacques Melitz. 2008. “Automatic Stabilizers: Social spending and automatic stabilizers in the OECD." Economic Policy 23 (56): 715-756.

Didier, Tatiana, Constantino Hevia, and Sergio Schmukler. 2010a. "Emerging Country Responses to the Global Crisis.” Mimeo. World Bank. Washington, DC.

- 2010b. "How resilient were developing countries to the global crisis?" Paper prepared for the IMF-World Bank Development Committee, Washington, DC.

Du, Luosha, Ann Harrison, and Gary Jefferson. 2011. "Do Institutions Matter for FDI Spillovers? The Implications of China's "Special Characteristics." NBER Working Paper Series 16767, NBER, Cambridge, MA.

Esquivel, Gerardo. 2011. "Mexico: Large, Immediate Negative Impact and Weak Medium-Term Growth Prospects." In The Great Recession and Developing Countries, ed. Mustapha K. Nabli, 359-399. Washington, DC: World Bank.

Fardoust, Shahrokh, Yongbeom Kim, and Claudia Sepúlveda. 2011. "Overview." In Postcrisis Growth and Development: A Development Agenda for the G-20, eds. Shahrokh Fardoust, Yongbeom Kim, and Claudia Sepúlveda, 1-62. Washington, DC: World Bank.

Frankel, Jeffrey A, and George Saravelos. 2010. "Are leading indicators of financial crises useful for assessing country vulnerability? Evidence from the 2008-09 global crisis." NBER Working Paper Series 16047, NBER, Cambridge, MA. 
Gorton, Gary B. 2008. “The Panic of 2007.” NBER Working Paper Series 14358, NBER, Cambridge, MA.

Harrison, Ann, and Andrés Rodríguez-Clare. 2009. "Trade, foreign investment, and industrial policy for developing countries.” NBER Working Paper Series 15261, NBER, Cambridge, MA.

Kaminsky, Graciela L., Carmen M. Reinhart, and Carlos A. Végh. 2004. "When it Rains, it Pours: Procyclical Capital Flows and Macroeconomic Policies." NBER Working Paper Series 10780, NBER, Cambridge, MA.

Lewis, Maureen, and Marjin Verhoeven. 2010. "Financial Crises and Social Spending: The impact of the 2008-2009 crisis." World Economics 11 (4): 79-110.

Lin, Justin Yifu. 2010. "New Structural Economics: A framework for rethinking development." Policy Research Working Paper 5197, World Bank, Washington, DC.

Lin, Justin Yifu, and Celestin Monga. 2010. "Growth Identification and Facilitation: The Role of the State in the Dynamics of Structural Change." Policy Research Working Paper 5313, World Bank, Washington, DC.

Maddison, Angus. 2007. Chinese Economic Performance in the Long Run: Second Edition Revised and Updated 960-2030 AD. Paris, France: OECD Development Centre.

Mishkin, Frederic S. 2010. "Over the Cliff: From the Subprime to the Global Financial Crisis." NBER Working Paper Series 16609, NBER, Cambridge, MA.

OECD. 2010. Perspectives on Global Development 2010: Shifting Wealth. OECD. Paris

Perotti, Roberto. 1999. "Fiscal policy in good times and bad." Quarterly Journal of Economics 114 (4): 1399-1436.

Talvi, Ernesto, and Carlos A. Végh. 2000. "Tax base variability and procyclical fiscal policy." NBER Working Paper Series 7499, NBER, Cambridge, MA.

World Bank. 2010a. Global Monitoring Report 2010: The MDGs after the Crisis. Washington, DC: World Bank.

.2010b. "Research for Development: A World Bank perspective on future directions for research.” Policy Research Working Paper 5437, World Bank, Washington, DC.

.2010c. "The External Environment for Developing Countries", http://go.worldbank.org/BEHG65ESB0, World Bank, Washington, DC

World Bank. 2011. Global Economic Prospects 2011: Navigating Strong Currents. Volume 2. Washington, DC: World Bank. 
Zoellick, Robert. 2010. "Democratizing Development Economics." Speech presented at Georgetown University, Washington, DC (29 Sept 2010). 